\title{
Sustainability Issues in Turkish Packaging
}

\author{
Dr. Ceyda Özgen
}

\begin{abstract}
The concept of sustainability refers to sustainable development or sustainable life. According to Bruntland Report published in 1987, the source of interest in sustainable development lies in the belief that existing human actions harm the environment and these actions will lead to serious negative results. As World Commission on Development and Environment published the report entitled Our Common Future in 1987, the concept of sustainable development began to be discussed in public domain. In the report, a series of social and environmental obstacles were defined including the unsustainable industrial development requiring global attendance.

Sustainability in design and also packaging design domain is receiving increasing attention due to sustainable development and environment. Increasing in consumption means much more packaging day by day. Designers and companies should be careful about designing sustainable for every design object and their packaging. Within the scope of this study, 'Concept of Sustainability' effects on company management decisions and sustainable packaging design will be emphasized. Impact of sustainable design criteria on company's organizational structure has been determined by a case study. Turkish packaging industry will be investigated for finding sustainability application of producers. Case study methods will be used to clarify the concept of the sustainability effects on sustainable management approaches, strategies and the decision- makers of the companies in the packaging sector. Glass and PET jars are examined to assess the sustainability of the current stages of the product design and production, as well as applications that include sustainable design and manufacturing innovations aimed to explore and investigate.
\end{abstract}

Keywords — Sustainability, Product Design, Turkish Packaging Industry, Glass Jar, PET Jar

\section{INTRODUCTION}

The concept of sustainability concerns sustainable development or sustainable life. In the Bruntland Report it is defined, as "Sustainable Development is development that meets the needs of the present without compromising the ability of future generations to meet their own needs". Later on, during the environment and development conference (UNCED, The Earth Summit), organized by United Nations, significant decisions were taken and the terms "sustainable consumption" and "development" began to gain more importance.

Within the scope of this study, the effects of the concept of sustainability on administrative decisions of companies and the subsequent effects of these decisions on sustainable product design are covered. The aim of this study includes "denoting

Dr. Ceyda Özgen is with Gebze Technical University, Turkey important points to producers to consider during the design process of sustainable products and putting these points into use". With the case study carried out in packaging sector, the aim is to determine the effects of sustainable design criteria of packing products on the organizational structure of companies. For the analysis of selected evaluation units, in the life-cycle analysis phase, the sustainability of energy and materials is researched. This study was conducted with two members of Packaging Industries Association in Turkey.

\section{WHAT IS SUSTAINABILITY?}

According to Bruntland Report published in 1987, the source of interest in sustainable development lies in the belief that existing human actions harm the environment and these actions will lead to serious negative results [1]. As World Commission on Development and Environment published the report entitled Our Common Future in 1987, the concept of sustainable development began to be discussed in public domain. In the report, a series of social and environmental obstacles were defined including the unsustainable industrial development requiring global attendance. To remove these obstacles, the following were advised; efficient utilization of resources in the industry and activities related to industry, less pollution and less waste production, utilization of renewable resources instead of non-renewable resources, reducing side effects on human health and the environment [2].

Later in 1992, during United Nations' Conference on Environment and Development (UNCED, The Earth Summit) organized in Rio, following significant decisions taken, the terms "sustainable consumption" and "development" began to gain more importance. The aim of the concept of sustainable development includes rational use of natural resources by protecting environmental values, reducing the use of resources and elevating quality of life [3].

\section{WHAT IS SUSTAINABLE DESIGN?}

The word "to design" is defined as "the creative act of stating a problem - consisting of decisions made to achieve the aims of the design - and solving it during various stages of the design act" [4]. Design is described as a creative activity incorporating the aim of establishing versatile features of objects, processes, services and systems through their overall lifecycles [5]. Otto (2005) defines sustainable product design as follows: "Sustainable design should deliver the best (social, environmental, and economic) performance or result for the least (social, environmental and economic) cost". This strategic approach is defined as the design of products, processes, services and systems. It is concerned with the instability between the demands of the society, environment 
and the economy. The system defined here is a system that aims to dissolve this instability and it incorporates an overall thinking process about the effects of these three areas now and in the future [6].

Tischner and Charter (2001) argue that sustainable design means more than eco-design or design for the environment. As for sustainable design, social and ethical components are juxtaposed together with economic and environmental ideas into the life-cycle of the product [3]. Sustainable design may also be defined as environmentally responsible product design and development, which incorporates a product life-cycle perspective together with approaches integrating work, culture and organizational skills [7].

Papanek (1984) states, "Industrial designers, industries and administrations should all together give an answer to the question of how much social and ecological harm is done to our society" [8]. In his book entitled Design for the Real World, Papanek claims industrial designers, industries and administers are all subject to environmental responsibility.

"The eco-design of energy-using products" directive (EUP) defines sustainable design as "environmental features should be integrated into product design to improve performance, sustainable design criteria should be provided all throughout the life-cycle, it should include purchase of raw materials, manufacturing, packaging, transportation and distribution, installation and maintenance, use and end-of-life stages based on sustainable design needs" [9]- [10]- [11]. Sustainable design should be compatible with the current corporate culture in order to increase economic value and reduce environmental damage. The word sustainability refers to ecology and economics that are inextricably adhered to good design in design practices [3].

Design actions for sustainability are different from general design activities with their environmental assessments, solution-seeking methodologies and strategy definitions. Moreover, the designer's expertise in sustainable design is more influential than sustainable design tools in defining environmental assessment and strategy [12].

\section{PACKAGING DESIGN}

\section{A. Sustainable Packaging}

Commercial packaging was developed in the 1700s. With the developments taken place in those years, the focus was on the practical function of the package rather than on its aesthetic quality. In the $19^{\text {th }}$ century, when transcontinental travel and shipping started, the travel time was quite long so a need to pack and ship products safely without spoilage arose.

As Robert Opei (1991) states: "the main function of packaging is to protect the product (as we expend its existence and provide distribution) make the product meet other products but avoid drawing the product away from its own standing position" [13]. Opei points to packaging design as an element of marketing and underlines its consequence for today. Paul Southgate, the author of Total Branding by Design (1994), and James Pilditch, the author of The Silent Salesman (1973) both wrote about the significance of packaging as and instrument of marketing [14]- [15].

Every industrial product - produced by an industry- is packaged somehow and is sent to its final consumer. Because of this reason, the main function of packaging is to preserve and protect the product it carries in. However, packaging plays an intermediary role in communication taking place between the product and the consumer in the retail area [16].

Results of research presented in International Association of Packaging Research Institutes (IAPRI) conference in 2004 show that it is difficult for most of the participants to define packaging and sustainability as complementary [17]. The organization argues that for sustainable packaging, the products should comply with the following four qualities; Efficient: meet social and economic targets; Effective: meet targets of effective use of materials, energy and water as much as possible; Cyclic: recyclable within industrial and environmental systems, and Safe: non-toxic and non-polluting.

\section{B. Turkish Packaging Industry}

Packaging has an increasingly vital role for marketing various agriculture and food products and other non-food products produced in present and lately developing industrial branches and specifically for export goods. Turkish packaging industry is growing by $10 \%$ each year and becoming an important competitor in the global market. Approximately 5000 manufacturers are producing packaging products in Turkey. Most of these manufacturers are located in Istanbul, Izmir, Kocaeli, Gaziantep, Adana, Ankara, Konya and Balıkesir [18].

Significant changes have been taking place in life standards as a result of increase in per capita income in the last decade. Growing tendency for urbanization, in crease in average life span, changes in consumption habits and consumer expectations all lead to development of self-service methods in consumption centers. The organized retail trade percentage, which was a little above $20 \%$ in 2000 s, rose above $40 \%$. Since this percentage is above $80 \%$ in economically developed European Union countries and countries in North America, it may be argued that the demand for packaged goods will rise in Turkey too [19]. Gross production capacity of packaging industries in Turkey is presented in Table I.

TABLE I: PACKAGING INDUSTRY PRODUCTION CAPASITY OF 2007-2011 (ASSR 2007-2016)

\begin{tabular}{lrr}
\hline \hline Production types & 2007 (tons) & 2015 (tons) \\
Paper & 60.000 & 85.000 \\
Cardboard & 415.000 & 577.000 \\
Corr. Cardb. & 1.370 .000 & 2.031 .000 \\
Plastic & 1.470 .000 & 2.988 .000 \\
Metal & 299.500 & 428.000 \\
Glass & 659.000 & 1.153 .000 \\
Wood & 385.000 & 510.000 \\
Total & 4.658 .500 & 7.772 .000 \\
\hline \hline
\end{tabular}

According to data collected between 2007-2016, it can be seen that glass packaging production had increased from 659,000 tons to $1,153,000$ tons. In the case of plastic packaging production, the production capacity had increased from 
$1,470,000$ tons to $2,988,000$ tons. In the Fig. 1 , there is a Turkish packaging sector production rate [19].

For the present and still developing industry in Turkey, packaging design has become a significant issue. Turkish packaging industry is growing by $10 \%$ each year and becoming an important competitor in the global market. For the period between 2001-2016, volume of plastic packaging production had tripled while glass packaging production had doubled. In the light of all these acquired information, it is seen that packaging design is quite significant for Turkish industry. Further studies in sustainable packaging design are crucial for both packaging sector and the local economy.

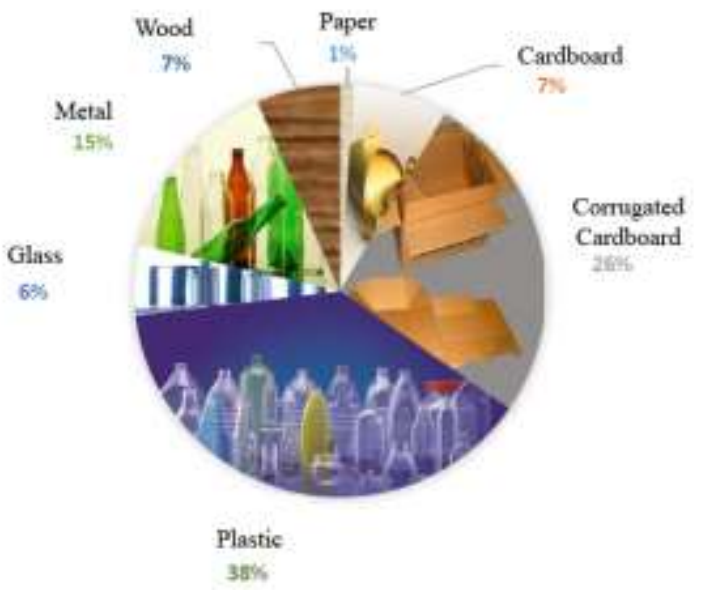

Fig. 1. Turkish packaging sector production rates [19]

\section{RESEARCH METHOD}

The aim of design research includes the discovery of man-made artifacts and their involvement in both academic research and manufacturing sector. Bayazit (2004) define research conducted in the field of design as follows: "Design research is a systematical research and information acquisition on design and design action" [20].

In the context of real life research, descriptive and revealing case studies are designed to collect research findings [21]. The case study is considered as the most effective method for a research in which a researcher cannot control or predict the experiment outcomes in real life context [21]. The two cases in which the case study method can be used optimally are described as follows. One of these is the search for a direct descriptive question "What happened?" or an explanatory question "Why and how?". Packages designed by manufacturers are analyzed with the criteria of sustainable packaging definition, and product-centered environmental management systems. For the evaluation units, life-cycle analysis method (energy consumption, material usage) is taken as an example to determine the effects of sustainable design. Three types of information resources were used: interview, documentation and physical objects. According to the model explained by Chung (1992), interviews were held at three levels [22]. For this research, both open-ended and close-ended interviews were carried out at strategic, tactical and operational levels.

\section{FINDINGS}

\section{A. General evaluation}

Closed-ended interview participants indicate that decisions on sustainable design are made mainly by the "Design Department" and the "Marketing Department". In response to the participants' answers to interview questions, the state and producers have a major role in the evaluation of responsibilities towards environmental issues and sustainability.

Within the scope of the closed-ended interviews, companies were asked to specify the legislations related to their products and activities. These legislations were pointed out as Packaging Waste Regulation, ISO 1440, Turkish Food Codex, EU Packaging and Packaging Waste Regulation and REACH. Participants were asked to evaluate the products produced by their companies in terms of compliance with the environmental legislations specified.

Participants of the companies surveyed in the research were asked to evaluate the sustainable design criteria applied to their products. Reducing material usage and diversity, reducing energy consumption, reusing the product, reducing the weight and volume of the product are the main issues.

In the closed-ended interview, companies were asked to evaluate the impact of environmental factors on their markets, taking into account their own products. Manufacturers were asked to rate the market pressures on the business in case of environmental issues. Both companies underlined that there was little pressure.

The companies were asked to evaluate how the development of environmental issues would provide a market advantage for their companies. It is seen that all employees of the both companies think that the development of environmental issues will increase brand reputation, effect corporate identity positively and this will provide competition power.

Company employees have stated that environmental issues are very important to them, but they underline that there is no competition in this sector about environmental issues. The difficulties faced by companies in implementing environmental issues seem to be expressed in terms of lack of understanding about environmental benefits, lack of financial resources, lack of customer demand, system and culture.

The employees of the companies surveyed within the scope of this research were asked about the actions they performed during the product development process and were asked to evaluate upon them. Selecting harmless materials, reducing weight and volume, using materials efficiently and reducing energy consumption are seen as the most important applications.

\section{B. Evaluation unit analysis}

As the evaluation units, olive oil bottles were selected as the most preferred and sold bottles of both packaging manufacturers. For this analysis, 2 products with similar forms produced by the two companies were examined within the scope of this research.

Companies didn't have material and energy consumption reports for each product in the production facilities. In this 
context, the anticipated value of recycling energy for analysis is unknown. In accordance with the Turkish Food Codex, the use of recycled material is taken as "0" for PET packaging. The rate of use of recycled glassware is assumed to be $30 \%$. Energy items spent for recycling, reuse, improvement, waste, transportation and service for the packages produced from both materials are not included in the production reports.

Analysis of packages made from glass and PET materials presented in Table II are shown graphically in Fig 2, Fig 3, Fig 4, Fig5 and Fig 6.

\begin{tabular}{lllll}
\multicolumn{5}{c}{ TABLE II: GLASS AND PET PACKAGING } \\
\hline \hline Product & Company & Weight & $\begin{array}{l}\text { Production } \\
\text { energy }\end{array}$ & Product \\
\hline $\begin{array}{l}147735 \\
\text { glass jar }\end{array}$ & Company & $220 \mathrm{gr}$ & $0,378 \mathrm{kwh}$ & \\
$\begin{array}{l}350 \mathrm{ml} \\
\text { PET jar 350 }\end{array}$ & $\begin{array}{l}\text { Company } \\
\text { ml }\end{array}$ & $22 \mathrm{gr}$ & $0,01914 \mathrm{kwh}$ & \\
& 2 & & & \\
\hline \hline
\end{tabular}

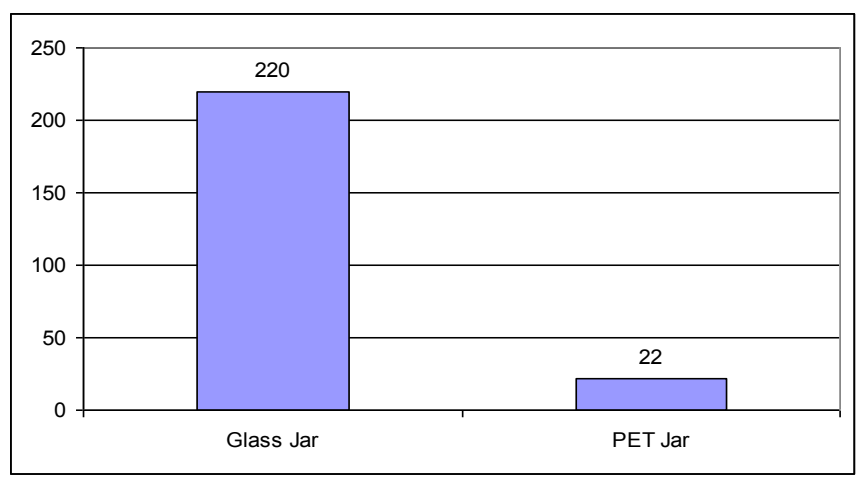

Fig. 2. Glass and PET bottles weight (gr).

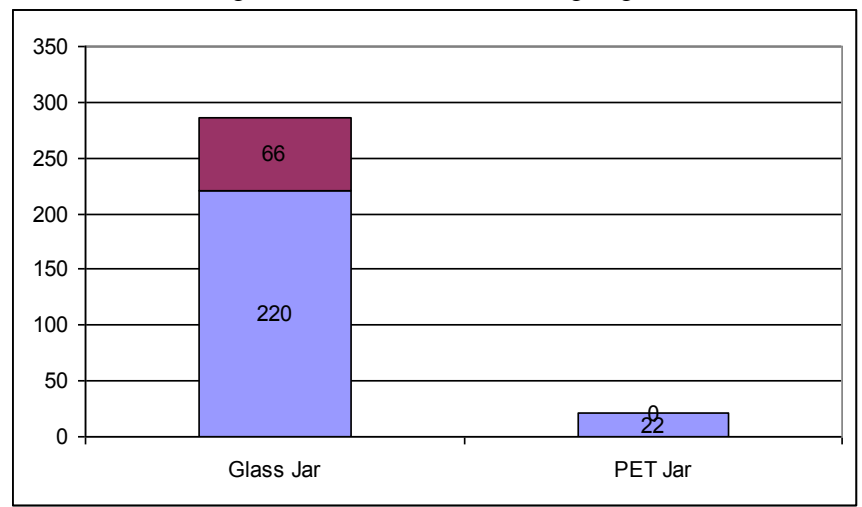

Fig. 3. Recycled materials using of glass and PET packaging (gr).

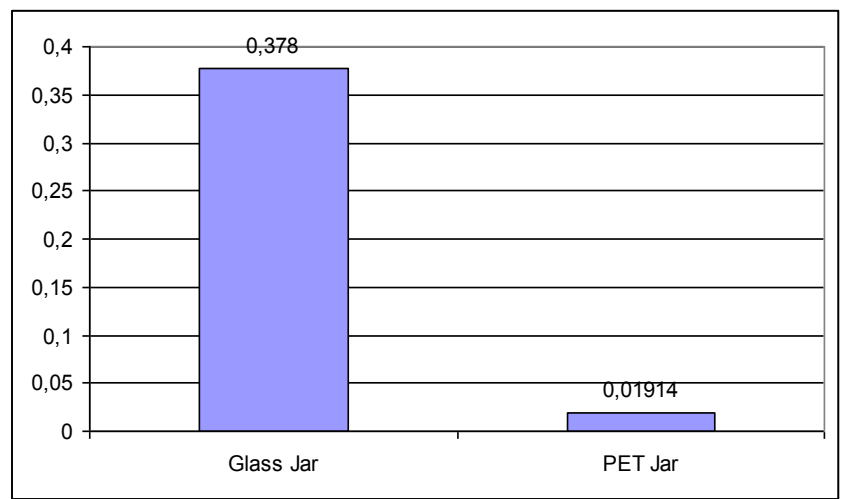

Fig. 4. Energy using of Glass and PET packaging (kwh).

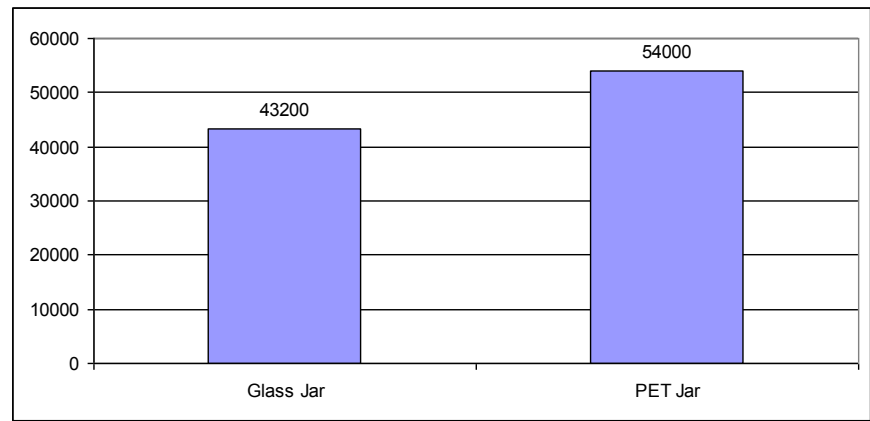

Fig. 5. Transportation of Glass and PET packaging (pieces).

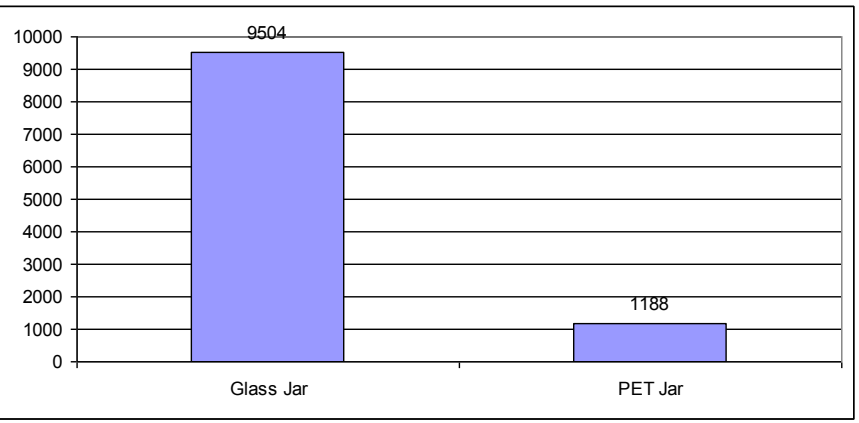

Fig. 6. Transportation of Glass and PET packaging $(\mathrm{kg})$.

The automatic calculators in Url-1 are used for the calculation of $\mathrm{CO}^{2}$ emitted in transporting glass and PET packages [23]. The parameters used in these calculations are given in Table III A simulated-road of $1302 \mathrm{~km}$ has been applied in the calculations carried out with these parameters. Table IV shows the $\mathrm{CO}^{2}$ releases. Fig. 7 shows $\mathrm{CO}^{2}$ emission figures for trucks carrying glass and PET packaging. Fig. 8 shows the fuel consumption of glass carrying trucks.

TABLE III: CO $^{2}$ CALCULATION PARAMETERS

\begin{tabular}{ll}
\hline \hline Truck size & 16 Ton \\
\hline Fuel consumption & $0.40 \mathrm{lt} / \mathrm{km}$ \\
Truck efficiency factor & $\% 80$ \\
$\mathrm{CO} 2$ emission/ fuel consump. & $2.630 \mathrm{~kg} / \mathrm{lt}$ \\
\hline \hline
\end{tabular}

TABLE IV: $\mathrm{CO}^{2}$ EMISSION

\begin{tabular}{lcccc}
\hline \hline $\begin{array}{l}\text { Transportation } \\
\text { Truck (16 tones) }\end{array}$ & $\begin{array}{l}\mathrm{CO}^{2} \text { emission } \\
(\mathrm{kg})\end{array}$ & $\begin{array}{l}\text { Efficiency } \\
\mathrm{CO}^{2} / \mathrm{tkm}\end{array}$ & gr & Weight $(\mathrm{kg})$ \\
\hline $\begin{array}{l}\text { Truck with glass } \\
\text { jar }\end{array}$ & 1016,7 & 82 & 9504 \\
Truck with PET jar & 127,1 & 82 & 1188 \\
\hline \hline
\end{tabular}




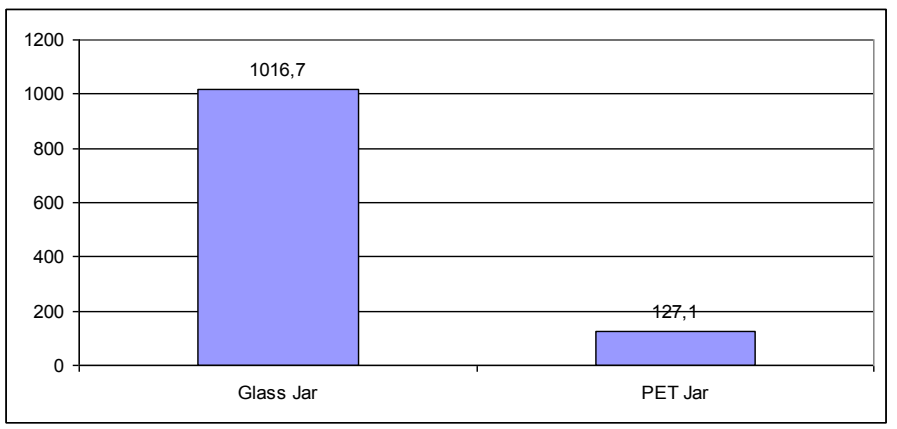

Fig. 7. $\mathrm{CO}^{2}$ emission figures for trucks carrying glass and PET packaging.

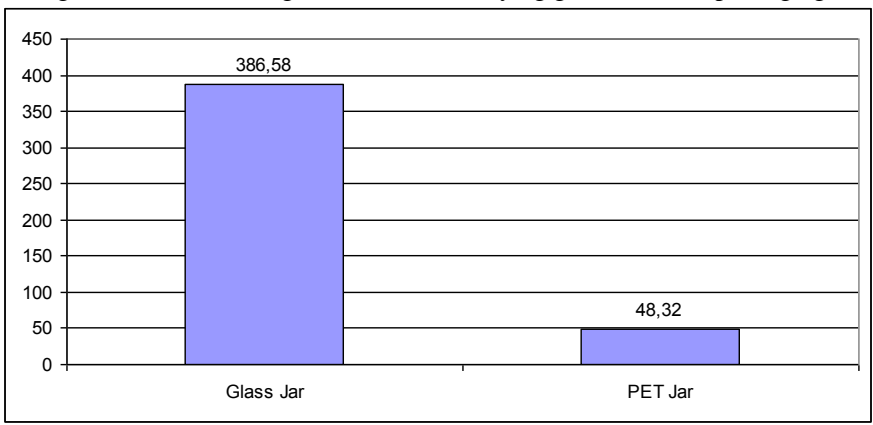

Fig. 8. $\mathrm{CO}^{2}$ Fuel consumption of trucks carrying glass and PET packaging

\section{CONCLUTION AND RECOMMENDATIONS}

\section{A. Conclusion}

Within the scope of the research, it is seen that in the applications of the companies surveyed, the idea of designing sustainable products is not targeted directly but because of the laws and regulations, competition creation and economic reasons, sustainable product criteria are applied partially. It is seen that the work carried out within the framework of company strategic plans generally includes reduction of materials at the product level, applications for easy and rapid production at the production stages, and reduction of the energy consumed in production.

In the findings section, it is observed that according to the common view of the companies, the government and producers both have vital roles about environmental issues and responsibilities towards sustainability. On the issue of being environmentally conscious in the designs they produce, manufacturers are mostly influenced by industries and other producers; and the customer factor comes as secondary. A further influential factor is determined as the European Union and consumers. It is seen that the most significant inducement about the environmental consciousness in the companies' work on sustainability can be listed as being in compliance with the legislation and regulations, consumer needs and market opportunities.

It is seen that the companies have a consensus on the necessity of being more active about environmental issues and actions in their organizations. Further observations show that all the employees of both of the companies think that the development of environmental issues will increase their brand reputation and positively effect corporate identity.

\section{B. Result of evaluation unit analysis}

Information on the amount of energy used to produce the product, the amount of material used to produce the product, the amount of recycled material usage, and the shipping conditions of the product from the production facility have been collected in the production, assembly, use-service and retirement phases. The production stages of glass and PET packaging in production facilities were examined and it was determined that the production stage for both packaging types was formed by one step.

When packaging is considered in the context of recycling, it is seen that packages made from glass materials can be recycled, but it has been determined that packages made from PET materials can not be used in food packaging as recycled PET materials.

For the analysis of the products examined within the scope of the research, the following material-energy use analysis model was carried out in accordance with the current production stages and the information obtained. Fig. 9 shows the model of evaluation analysis used for the packages examined in the research.

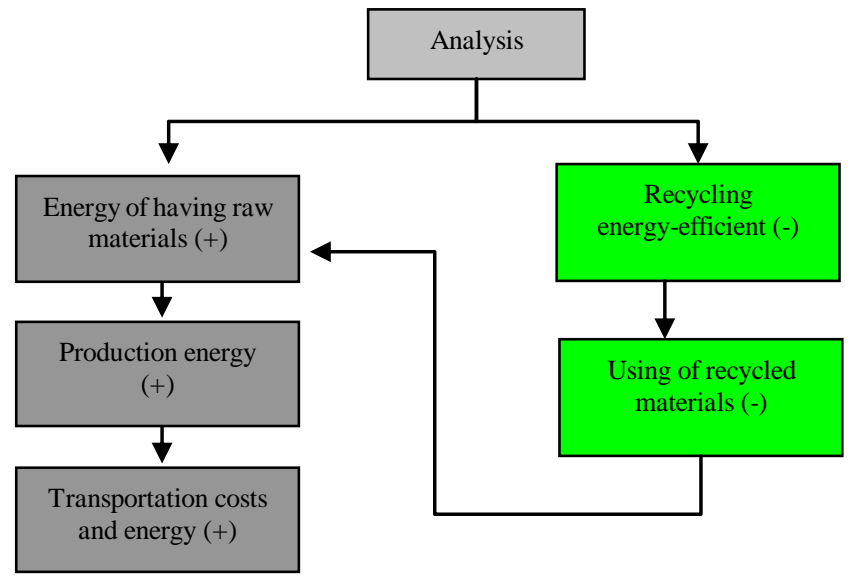

Fig. 9. The model of evaluation analysis used for the packages

Analysis based on packaging clearly shows that PET packaging is produced using much less material and energy than glass packaging, $\mathrm{CO}^{2}$ emissions are less in transportation of PET and in parallel to that less fuel is consumed during the transportation. These evaluations can be seen in Table V.

TABLE V: EVALUATION OF GLASS AND PET PACKAGING (GLASS JAR/ PET

\begin{tabular}{|c|c|c|c|c|}
\hline \multicolumn{5}{|c|}{ JAR) } \\
\hline & "Weight & $\begin{array}{l}\text { Production } \\
\text { energy }\end{array}$ & $\begin{array}{l}\text { Transportation } \\
\text { of piece }\end{array}$ & $\begin{array}{l}\text { Transportation } \\
\text { piece for } 1 \text { Unit kg } \\
\mathrm{CO}^{2}\end{array}$ \\
\hline $\begin{array}{l}\text { glass jar/ PET } \\
\text { jar }\end{array}$ & $\begin{array}{l}10 \\
\text { pieces }\end{array}$ & 19,7 pieces & 1,25 pieces & 10 pieces \\
\hline
\end{tabular}

Similar results have also appeared in the results of a study of baby food jars produced from glass and PET bottles [24]. Humbert et al. (2009) reported that plastic containers produced using $14-24 \%$ less energy, caused $28-31 \%$ less input on global warming, contained $31-34 \%$ less respiratory inorganic materials, caused $28-31 \%$ less terrestrial acidity and pollution 
[24]. Another work on sustainable packaging have the similar results [25].

As a result of the findings obtained, how realistic the discourse "glass is a nature-friendly material" has been open to debate. Although petroleum-derived PET material is seen as the enemy of the environment because of its source material, in accordance with the findings of this study and due to the efficiency of the production methods and transportation of PET, this acceptance turns out to be not true. A multidisciplinary team must be research this issue to produce new data for enlightening all aspects of these materials using for product.

\section{Recommendations}

It is clear that sustainable production design and methods are important contributors to the solution of environmental problems such as waste reduction and natural resource conservation, reducing production costs and thus reducing product prices and operating profits. In order for sustainable production systems to be implemented in a healthy and effective way, it is necessary for the term sustainability to be in the management decisions of the company, and starting from the design stage, the products should be dealt with and developed in line with these criteria.

How much the concept of sustainability is present in design and production in Turkey is an issue of debate. Turkey's institutional capacity in terms of sustainability has been reported as limited compared to examples from the European Union [26]-[27]. Küçüksayraç (2015) further states that for the first stage of innovation support, sustainability-related services and tools need to be developed more quickly for sustainable design [28].

The European Union Compliance Criteria Framework, Kyoto Protocol guidelines and related laws and regulations point to the fact that, manufacturers have to use sustainable product design and manufacturing methods and inevitably have to be informed and implement necessary applications.

\section{REFERENCES}

[1] T. Bhamra, S. Evans, S.F. Vander Zwan, and M. Cook, "Moving from Eco-Products to Eco-Services", International Ecotechnology Research Centre, Cranfield University, Journal of Design Research, ch. 1, 2, 2001.

[2] J. Gertsakis, H. Lewis, "Sustainability and the Waste Management Hierarchy", A Discussion Paper on the Waste Management Hierarchy and Its Relationship to Sustainability. Mellbourne: EcoRecycle Victoria, 2003.

[3] U. Tischner and M. Charter, Sustainable Product Design in Sustainable Solutions: Developing Products and Services for the Future, Ed. M. Charter and U. Tischner, Sheffield, UK: Greenleef Publishing, 2001, pp. 118-138.

[4] N. Bayazıt, Endüstri Ürünlerinde ve Mimarllkta Tasarlama Metotlarina Giriş, İstanbul: Literatür Yayıncılık, 1994.

[5] ICSID, (March 2014). International Council of Societies of Industrial Design [Online]. http://www. icsid.org/about/about/articles31.htm

[6] B.K. Otto. (September 2005). About :Sustainability, [Online]. http://www.designcouncil.org 2005.

[7] N.K. Kim, "A Model of Component-based Product-Oriented Environmental Management System (C-POEMS) for Small and Medium-sized Enterprises", PhD Thesis, School of Engineering and Design, Brunel University, London, 2008.

[8] V. Papanek, Design For The Real World, London: Van Nostrand Reinhold Co, 1984.

[9] EC, Proposal for a Directive of the European Parliament and of the Council on establishing a framework for the setting of Eco-design requirements for
Energy-Using Products and amending Council Directive 92/42/EEC. Brussels: European Commission 453 final, 2003.

[10] EU, European Union Directive 2005/32/EC of the European Parliament and of the Council, Establishing a framework for the setting of ecodesign requirements for energy-using products and amending Council Directive, 92/42/EEC and Directive 96/57/EC and 2000/55/EC of the European Parliament and of the Council, 2005 [Online]. http://ec.europa.eu/environment/waste/directive2005:32:D09242EEC_ind ex.htm

[11] M. Goosey, "End-of-life Electronics Legislation - An Industry Perspective", Circuit World, vol. 30, 2, pp. 41-45, 2004. https://doi.org/10.1108/03056120410512235

[12] F. Vallet, Eynard, B., D. Millet, S.G. Mahut, B. Tyl, G. Bertoluci, “ Using eco-design tools: an overview of experts' practices", Design Studies, vol. 34 (3), pp. 345-377, 2013. https://doi.org/10.1016/j.destud.2012.10.001

[13] R. Opie, Packaging Source Book, A Visual Guide To a Century of Packaging Design, Little, UK: Brown and Company, 1991.

[14] P. Southgate, Total Branding By Design: Using Design To Create Distinctive Brand Identities, UK: Kogan Page, 1994.

[15] J. Pilditch, The Silent Salesman: How to Develop Packaging That Sells, United States: Brookfield Publishing Co., 1973.

[16] N. Bayazıt, “ Endüstriyel Tasarım Olarak Ambalaj”, Yapı Dergisi, Sayı 284, pp. 101-105, July 2005.

[17] H. Lewis and K. Sonneveld, "Unwrapping the Discourse: Product Stewardshipand Sustainability in the Australian Packaging Industry", 14th IAPRI World Conference on Packaging, Lidingö, Sweden, June 13-16, 2004.

[18] S. Bektaşoğlu ve B. Esen, Ambalaj Sanayi. Ankara: İGEME, 2007.

[19] ASSR, Ambalaj Sanayicileri Derneği, Ambalaj Sanayi Sektör Raporu, İstanbul, 2016.

[20] N. Bayazit, "Investigating Design: A Review of Forty Years of Design Research", Design Issues, Volume 20, Number 1, pp. 16-29, 2004. https://doi.org/10.1162/074793604772933739

[21] R. Yin, Case Study Research: Design and Methods, CA: Sage Publish, 2003.

[22] K.W. Chung, "The Meaning of Design Management and lts Strategic Value", Design Management Institute Fourth International Design Management Research and Education Forum, London Business School, 1992.

[23] Url1 (March 2013). CO2 Calculater [Online]. Available: http://www.tschudilogistics.com/page/121>

[24] S. Humbert, V. Rossi, M. Margni, O. Jolliet, Y. Loerincik, "Life cycle assessment of two baby food packaging alternatives: glass jars vs. plastic pots", International Journal of Life Cycle Assess, Volume 14, issue 2, pp. 95-106, March 2009. Available: doi:10.1007/s11367-008-0052-6

[25] C. Özgen, "Sürdürülebilirlik Kavramının Firma Stratejisi Açısından Ambalaj Tasarımına Etkilerinin İrdelenmesi”, PhD Thesis, Department of Industrial Product Design, , Fen Bilimleri Enstitüsü, İstanbul Teknik Üniversitesi, İstanbul, 2013.

[26] TC ÇOB \& TTGV, TC Çevre ve Orman Bakanlı̆̆ \& Türkiye Teknoloji Geliștirme Vakfi, Türkiye'de Temiz Üretim Uygulamalarinın Yaygınlaştırlması için Çerçeve Koşulların ve Ar-Ge İhtiyacının Belirlenmesi Projesi. TC ÇOB ve TTGV, Türkiye, Ankara, 2010.

[27] E. Küçüksayraç, D. Keskin, H. Brezet, "Intermediaries and innovation support in the design for sustainability field: cases from the Netherlands, Turkey and the United Kingdom" Journal of Cleaner Production, 101, pp. 38-48, 2015. https://doi.org/10.1016/j.jclepro.2015.03.078

[28] E. Küçüksayraç, "Design for sustainability in companies: strategies, drivers and needs of Turkey's best performing businesses", Journal of Cleaner Production, 106, pp. 455-465, 2015. https://doi.org/10.1016/j.jclepro.2015.01.061 


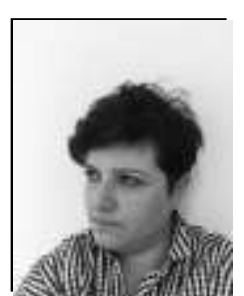

\section{Dr. Ceyda Özgen}

She was born in Istanbul/Turkey. She graduated as an Architect from Yıldız Technical University/ Istanbul. She got Master and Phd degree from Industrial Product Design Department at Istanbul Technical University/ Istanbul. She worked as a research assistant during master and Phd degree for Istanbul Technical University, Department of Industrial Product Design.

She is working at the Gebze Technical University/ working on sustainability lif, Department of Industrial Product Design. She is ity, life-cycle assessments, product design, design studio and jewellery design. 